\title{
AN APPROACH TO GEOTHERMAL RESOURCES AS A REGIONAL DEVELOPMENT DRIVER IN POLAND
}

\begin{abstract}
Geothermal energy has engaged researchers from various disciplines largely because it provides significant advantages over other renewable resources and has become one the most extensively used renewable resource worldwide. In addition to these technical parameters, geothermal resources are of an endogenous character i.e. their exploitation takes place where they are located. The aim of this article is to examine a possible scenario relating to the impact of geothermal resources on local development, based upon their primary energy-producing function. Geothermal energy exploited locally can positively influence the economic situation of a region in direct and indirect ways. Moreover, interest in this source of energy has been motivated by the desire to integrate sustainable development into national energy plans and the European Union's ambition to enhance its significance in community energy balances. Thus local production and consumption of geothermal heat and water should be a principle of local energy security for municipalities or regions with appropriate geological conditions. However, in the existing literature, its local development impact has been marginalized and insufficiently discussed by practitioners. This article attempts to close this gap and to establish development indicators that measure local development associated with the use of geothermal resources. Notwithstanding the relatively marginal importance national authorities have given geothermal resources to date, Poland was chosen as the main object of the research reported on here because of its particularly high geothermal potential. Empirical analysis of selected Polish municipalities with ongoing exploitation of geothermal energy allows us to assess the contribution of geothermal resources to municipal-level development indicators. The theoretical conceptualization underpinning this analysis is provided by endogenous growth theory as well as reflections on the precise definition of local development.
\end{abstract}

Keywords: geothermal resources, renewable resources, local development, endogenous growth

\section{INTRODUCTION}

Discussions about sustainability and energy security targets dominate the current approach to renewable resources. Nevertheless, the market for renewable resources is still relatively independent and state-decentralised while remaining connected to regional distribution networks and rather locally sourced. The literature on this theme has already recognized a positive relation between the use of renewable resources, the creation of employment and increases in local budgets. These potential benefits combined with the reliability of renewable resources weigh heavily in favor of continued investment and

${ }^{1}$ Katarzyna A. Kurek, Alumnus of Erasmus University Rotterdam, Faculty of Economics and Business, kaankurek@hotmail.com. 
development of the sector. This paper focuses on geothermal resources which, compared to all other renewables, remain predominantly under the control and competence of regional or local authorities. The aim of this study is to make an initial assessment of the local component in the geothermal resource management and subsequently discuss the relation between renewable resources (specifically geothermal energy) and local development. A leading argument is that geothermal resources have a positive impact on the performance of the community that exploits them; consequently, the core part of this paper consists of an attempt to identify indicators to measure the impact of geothermal resource use on local development. If the use of geothermal renewables induces quantitative and/or qualitative changes in the development trajectories of local economies, indicators depicting such changes need to be constructed. The present article examines the principle development indicators discussed in the literature with a view to establishing an approach that will contribute to the characterization of the relation between renewable resource exploitation and local development performance indicators. As a result of the multi-criteria comparative analysis conducted in this research, a matrix of indicators was formulated that can be applied to the impact assessment of geothermal resources at the level of a local/regional administrative unit.

In spite of rare attempts to analyze the contribution of geothermal resources to the regional and/or local economy, the subject remains under-researched and much scope for new interpretations remains.

\section{RESEARCH AIMS AND LITERATURE REVIEW}

Unlike other renewables that provide power on an intermittent basis, geothermal energy is continuous and independent of the weather or climatic conditions. Geothermal energy technologies have been found optimal as substitutes for coal-generated energy discuss Asif and Munner ${ }^{2}$. At the present stage of expansion of this resource, it saves an equivalent of around 77 million barrels of oil worldwide used for electricity generation and the production of heat ${ }^{3}$. This study is dedicated to examining geothermal energy in Poland, which was chosen both because of its technical potential and the fact that its widespread character makes it a potential resource that can be locally regulated. Polish geothermal potential is calculated to be present under almost $80 \%$ of the earth's crust in the country, one of the highest levels in Europe; technically $40 \%$ of this potential is ready to deliver economically attractive geothermal heat and energy. Poland is capable of producing $625.000 \mathrm{PJ}$ of geothermal energy, whereas the annual energy consumption is around $4000 \mathrm{PJ}^{4,5}$. Furthermore, this technical potential corresponds to $30 \%$ of the

${ }^{2}$ M. Asif, T. Muneer, Energy supply, its demand and security issues for developed and emerging economies, „Renewable and Sustainable Energy Reviews”, 2007/11(7), pp. 1388-1413.

3 P.M. Wright, S.H. Ward, H.P. Ross, R.C. West, State-of-the-art geophysical exploration for geothermal resources, „Geophysics”, 1985/50(12), pp. 2666-2696.

${ }^{4}$ R. Ney, Zasoby energii geotermalnej w Polsce $i$ możliwe kierunki jej wykorzystania, [w:] Materiały z seminarium naukowego pn. „Problemy wykorzystania energii geotermalnej i wiatrowej w Polsce", Wyd. IGSMiE PAN. Kraków-Zakopane 1997.

${ }^{5}$ W. Bujakowski, Wykorzystanie wód termalnych w Polsce (stan na rok 2009), „Przegląd Geologiczny", 2010/58(7), pp. 580-588. 
domestic demand for heat calculate Turski and Sekret ${ }^{6}$. Geothermal energy is applied for the purposes of communal heating, drinking water, provision of water-based recreational centres, and there exist credible perspectives for increased application in cooling, food processing, farming and industry ${ }^{7}$. Since geothermal resources are a natural resource located on public land, public utilities and authorities are in a position to develop it. By proposing that endogenous resources constitute a major source of development Romer ${ }^{8}$ initiated the theoretical debate over natural resources exploitation as a driver of endogenous growth.

One aspect of the endogenous growth model addresses the way in which natural resources in particular and the environment in general, with the former seen as endogenous public goods. Thus, following Brander and Taylor ${ }^{9}$, Dalton et al. ${ }^{10}$, Plummer et al. $^{11}$, and the US Environmental Protection Agency ${ }^{12}$, endogenous resources can be seen as a core element in regional specialization and a stimulus to growth in small-scale economies, with local communities identified as the primary recipients of the benefits and externalities connected with the exploitation of renewable resources. Rybach ${ }^{13}$, Szymańska and Chodkowska-Miszczuk ${ }^{14}$ suggest that developing renewable resources enhances and revitalizes the economic potential of a locality. Geothermal energy considered as an endogenous resource is produced and exploit locally and it therefore generates added value for local communities find Andritsos, et al. $2003^{15}$ and Lund ${ }^{16}$. The fact researchers have found that its use has minimal negative environmental impact, its influence on inhabitants' health are positive and it has significant capacity to create direct and ongoing benefits for local residents has stimulated the desire to exploit this resource. Jarczewski et al. ${ }^{17}$ argue that optimal conditions for geothermal exploitation are found in

${ }^{6}$ M. Turski, R. Sekret, Konieczność reorganizacji systemów cieplowniczych $w$ świetle zmian zachodzacych w sektorze budowlano-instalacyjnym, ,Rynek Energii”, 2015/4(119), pp. 27-34.

7 B. Kępińska, Geothermal energy country update for Poland, 2010-2014, „Proceedings World Geothermal Congress", 2015, (p. 11).

8 P.M. Romer, The origins of endogenous growth, „The journal of economic perspectives", 1994/8(1), pp. 3-22.

9 J.A. Brander, M.S. Taylor, The simple economics of Easter Island: A Ricardo-Malthus model of renewable resource use, „American economic review”, 1998, pp. 119-138.

${ }^{10}$ T.R. Dalton, R.M. Coats, B.R. Asrabadi, Renewable resources, property-rights regimes and endogenous growth, „Ecological Economics”, 2005/52(1), pp. 31-41.

${ }^{11}$ P. Plummer, M. Tonts, K. Martinus, Endogenous growth, local competitiveness and regional development: Western Australia's Regional Cities, 2001-2011, „Journal of economic and social policy", 2014/16(1), p. 1-29.

12 https://www.epa.gov/sites/production/files/2015 (accessed 10.07.2016).

${ }^{13}$ L. Rybach, The future of geothermal energy and its challenges, „Proceedings World Geothermal Congress April 2010", 2010, (vol. 29).

${ }^{14}$ D. Szymańska, J. Chodkowska-Miszczuk, Endogenous resources utilization of rural areas in shaping sustainable development in Poland, „Renewable and Sustainable Energy Reviews”, 2011/15(3), pp. 1497-1501.

${ }^{15}$ N. Andritsos, P. Dalampakis, N. Kolios, Use of geothermal energy for tomato drying, „GeoHeat Center Quarterly Bul”, 2003/24(1), pp. 9-13.

${ }^{16}$ J.W. Lund, Freeston D.H., World-wide direct uses of geothermal energy 2000, „Geothermics”, 2001/30(1), pp.29-68.

${ }^{17}$ Jarczewski W., Huculak M., Dej M., Wykorzystanie Energii Geotermalnej w Polsce /The use of geothermal energy in Poland, „Prace Geograficzne”, 2015(141), p. 87. 
locations that are at or in close proximity to the source of renewable geothermal energy, namely in relatively small and medium sized municipalities with a dense network of housing and supporting infrastructure. Since the resource is exploited locally, it directly or indirectly promotes the local job market. Indeed, Johansson et al. ${ }^{18}$ have observed socioeconomic development associated with this type of energy generation. Consequently, Fridleifsson ${ }^{19}$, $\mathrm{Kagel}^{20}$ and Sanchez-Velasco et al. $2003^{21}$ felt able to argue that geothermal exploitation stimulates local development by creating new economic opportunities and allowing pre-existing social boundaries to be transcended. According to Akella et $a .^{22}$ and Wei et al. $2009^{23}$ besides direct benefits such as energy generation, geothermal resources produce induced benefits consisting mostly of employment and income circulation in domestic markets. The International Renewable Energy Agency estimates that over 160,000 direct geothermal jobs were created worldwide in $2015^{24}$ and that local employment creation would experience double-digit growth in the coming decade. Lehr et al. ${ }^{25}$, Ragwitz et al. ${ }^{26}$ and Panwar et al. ${ }^{27}$ have argued that geothermal energy's substitution of fossil fuel use would induce additional economic effects in domestic markets. Indications from the literature review suggest that the use of geothermal resources positively impacts on local socio-economic development. Its endogenous character ${ }^{28}$ permits us to conclude that local communities and domestic markets are potentially the initial recipients and beneficiaries of harnessing this resource.

${ }^{18}$ T.B. Johansson, H. Kelly, A.K.N. Reddy, R.H. Williams, Renewable Fuels and Electricity for a Growing World Economy: Defining and Achieving the Potential, „Energy Studies Review”, 1992/4(3), pp. 201-212.

${ }^{19}$ I.B. Fridleifsson, Geothermal energy for the benefit of the people, ,Renewable and sustainable energy reviews", 2001/5(3), pp. 299-312.

${ }^{20}$ A. Kagel, A handbook on the externalities, employment, and economics of geothermal energy. Geothermal Energy Association, Washington DC, October 2006.

${ }^{21}$ R. Sánchez-Velasco, M. López-Díaz, H. Mendoza, R. Tello-Hinojosa, New CFE geothermal village power plant in Mexico bestows local residents with prosperity - and children with ice cream, Comisión Federal de Electricidad, Mexico 2003.

22 A.K. Akella, R.P. Saini, M.P. Sharma, Social, economical and environmental impacts of renewable energy systems, „Renewable Energy”, 2009/34(2), pp. 390-396.

${ }^{23}$ M. Wei, S. Patadia, D.M. Kammen, Putting renewables and energy efficiency to work: How many jobs can the clean energy industry generate in the US?, „Energy policy”, 2010/38(2), pp. 919-931.

24 http://www.irena.org/DocumentDownloads/Publications/IRENA_RE_Jobs_Annual_Review_ 2015.pdf (accessed 10.07.2016).

${ }^{25}$ U. Lehr, J. Nitsch, M. Kratzat, C. Lutz, D. Edler, Renewable energy and employment in Germany, „Energy policy”, 2008/36(1), pp. 108-117.

${ }^{26}$ M. Ragwitz, W. Schade, B. Breitschopf, R. Walz, N. Helfrich, M. Rathmann, G. Resch, C. Panzer, T. Faber, R. Haas, C. Nathani, The impact of renewable energy policy on economic growth and employment in the European Union, European Commission, DG Energy and Transport, Brussels, Belgium 2009.

27 N.L. Panwar, S.C. Kaushik, S. Kothari, Role of renewable energy sources in environmental protection: a review, „Renewable and Sustainable Energy Reviews”, 2011/15(3), pp. 1513-1524.

${ }^{28}$ U. Chakravorty, J. Roumasset, K. Tse, Endogenous substitution among energy resources and global warming, „Journal of Political Economy”, 1997/105(6), pp. 1201-1234. 
The present article focuses on local development that is based on the identification of the potentialities of the endogenous resources of a given community or area. According to Szewczuk et al. ${ }^{29}$ local development is a process of making changes within a territory that comprises cities, municipalities or counties and the research reported on here would include the use of geothermal resources as an important change factor. While the literature presents a wide range of definitions of local development, recent findings emphasize two key concepts: sustainability and economic welfare. The classical approach, as presented by Coffey and Polèse ${ }^{30}$ defines local development in terms of sustainable economic growth as measured by the expansion of entrepreneurship, and the growth of firms and the overall economic wellbeing of a community. According to these authors, endogenous elements i.e. any local advantages, contribute to a local spirit of entrepreneurship. Pike $e t$ $a l .^{31}$, Walker et $a l^{32}$ and Del Rio and Burguillo ${ }^{33}$ stress the importance of using endogenous resources to promoting the sustainability of local development as measured by their socio-economic impact on communities. Complementary work by Kożuch ${ }^{34}$,Strojny and Baran ${ }^{35}$ and Pires et al. ${ }^{36}$ refer to four factors that are essential to assessing the possibilities for sustainable local development: social potentialities, economic opportunities, environment conditions and/or constraints, and institutional capacity. Such assessments deploy development indicators, the observation of which serves to verify the hypothesis that local exploitation of geothermal resources can have positive socioeconomic impacts. The literature also recommends the construction of indicators that capture changes in local development. Following Weisbrod and Weisbrod ${ }^{37}$, Malecki, ${ }^{38}$, Olewiler $^{39}$ and Scipioni et al. ${ }^{40}$ a set of measures reflecting the level of economic

${ }^{29}$ A. Szewczuk, M. Kogut-Jaworska, M. Zioło, Rozwój lokalny i regionalny. Teoria i praktyka, Wydaw. CH Beck, Warszawa 2011.

${ }^{30}$ W.J. Coffey, M. Polese, The concept of local development: a stages model of endogenous regional growth, „Papers in Regional Science”, 1998/55(1), pp. 1-12.

31 A. Pike, A. Rodríguez-Pose, J. Tomaney, Local and regional development, Routledge NY 2006.

${ }^{32}$ G. Walker, S. Hunter, P. Devine-Wright, B. Evans, H. Fay, Harnessing community energies: explaining and evaluating community-based localism in renewable energy policy in the UK. „Global Environmental Politics”, 2007/7(2), pp. 64-82.

${ }^{33}$ P. Del Río, M. Burguillo, Assessing the impact of renewable energy deployment on local sustainability: Towards a theoretical framework, „Renewable and sustainable energy reviews”, 2008/12(5), pp. 1325-1344.

${ }^{34}$ A. Kożuch, Rola samorządu terytorialnego we wspieraniu rozwoju lokalnego, „Instrumenty zarządzania rozwojem w przedsiębiorczych gminach”, 2011, pp. 9-26.

35 J. Strojny, M. Baran, Przedsiębiorczość i innowacyjność w zarzadzaniu rozwojem JST, „Przedsiębiorczość-Edukacja”, 2014/10, pp. 187-198.

${ }^{36}$ S.M. Pires, T. Fidélis, T.B. Ramos, Measuring and comparing local sustainable development through common indicators: Constraints and achievements in practice, „Cities”, 2014/39, pp. 1-9.

${ }^{37}$ G. Weisbrod, B. Weisbrod, Measuring economic impacts of projects and programs, Economic Development Research Group, 10 (1997).

${ }^{38}$ E. Malecki, Jockeying for position: what it means and why it matters to regional development policy when places compete, ,Regional studies”, 2004/38(9), pp.1101-1120.

39 N. Olewiler, Environmental sustainability for urban areas: The role of natural capital indicators, „Cities”, 2006/23(3), pp. 184-195. 
activities and social conditions in a given area could include, for example, economic opportunities, local environmental conditions, the demographic profile and dynamics of the society, levels of technological integration, and local budgetary resources.

\section{RESEARCH METHOD}

The object of the empirical analysis conducted in this research is a set of nine Polish municipalities that have a minimum 10 years' experience of accessing geothermal reserves and operating within a functioning energy network: Szaflary, Zakopane, Biały Dunajec, Poronin, Bukowina Tatrzańska, Mszczonów, Uniejów, Stargard Szczeciński and Pyrzyce, subsequently referred to as the geothermal municipalities ${ }^{41}$. Although there are about 25 Polish municipalities that are in various phases of using geothermal energy and water, only this sample has exploited it long enough for changes in the development indicators to be appropriately observed ${ }^{42}$.

Multi-criteria analytical methods allow us to conduct an impact assessment - in this case, the impact on domestic markets of the harnessing of geothermal resources. The process of verifying the research question begins by formulating a research criterion, in this case a descriptive one, summarizing the demographic, socio-economic and technical dimensions of development.

Empirical observation of development indicators provides a measure of the development gap. In effect a synthetic indicator is delivered that allows us to compare trends in various development indicators. The expected results would be that a high value of the calculated synthetic variable would reflect a high level of development i.e. a positive change. However, the possible alteration requires a comparison, thus benchmarking is employed to compare each geothermal municipality with a matching group of municipalities. This is a common method used in regional economics to assess trends in performance indicators ${ }^{43}$ and is therefore appropriate and relevant for determining the extent of Polish geothermal municipalities' competitive advantage.

\section{DATA ANALYSIS AND RESULTS}

The local development effects assumed to be associated with the use of geothermal resources are tested by way of an analysis focusing on the performance dynamics of key development indicators. Drawing upon the literature review above, Table 1 presents a matrix of 24 diagnostic variables (sub-indicators) grouped in six thematic categories

40 A. Scipioni, A. Mazzi, M. Mason, A. Manzardo, The Dashboard of Sustainability to measure the local urban sustainable development: The case study of Padua Municipality, „Ecological indicators", 2009/9(2), pp. 364-380.

${ }^{41}$ Geothermal establishments in municipalities: Szaflary (1993), Biały Dunajec (1996), Pyrzyce (1997), Mszczonów (1999), Uniejów (2001), Zakopane (2001), Poronin (2001), Stargard Szczeciński (2005), Bukowina Tatrzańska (2005).

${ }^{42}$ Estimation of geothermal municipalities based on the information from Polish Geothermal Society (http://www.energia-geotermalna.org.pl).

${ }^{43}$ U. Kobylińska, E. Glińska, Wykorzystanie benchmarkingu $w$ doskonaleniu systemów zarządzania placówkach samorzadu terytorialnego, [w:] B. Plawgo (red), „Polska Wschodnia - zarządzanie rozwojem", WSAP, Białystok 2008.

${ }^{44}$ S. Gędek, J. Strojny, M. Kościółek, Wykorzystanie benchmarkingu w zarządzaniu strategicznym administracja publiczna, „Przedsiębiorczość i Zarządzanie”,2013/14(12, cz. 2 Zarządzanie w XXI wieku. Menedżer innowacyjnej organizacji. Część II), pp. 127-142. 
(indicators) generated from data provided by the Central Statistical Office of Poland (Główny Urząd Statystyczny- GUS). The standardized database stretches back over the last 20 years, with geothermal operations in Poland being observed in the same time frame i.e. 1995-2015. In choosing the most relevant indicators, it was necessary to take into consideration both the date of observations and the limitations of the GUS database.

Table 1. Local development categories and their indicators

\begin{tabular}{|c|c|c|c|c|c|}
\hline \multicolumn{6}{|c|}{ Categories of local development indicators } \\
\hline $\begin{array}{l}\text { Population } \\
\text { Resources }\end{array}$ & $\begin{array}{c}\text { Local } \\
\text { Economy }\end{array}$ & $\begin{array}{c}\text { Local } \\
\text { government }\end{array}$ & Tourism & Infrastructure & Quality of Life \\
\hline $\begin{array}{l}\text { Internal } \\
\text { migration/ } \\
10.000 \\
\text { inhabitants }\end{array}$ & $\begin{array}{c}\% \text { of } \\
\text { employed } \\
\text { inhabitants }\end{array}$ & $\begin{array}{c}\text { Municipal } \\
\text { income/inhabi- } \\
\text { tant }\end{array}$ & $\begin{array}{l}\text { Polish tourists } \\
\text { accommodated/10 } \\
00 \text { inhabitants }\end{array}$ & $\begin{array}{l}\text { Industrial and } \\
\text { domestic water } \\
\text { consumption } \\
\text { /inhabitant }\end{array}$ & $\begin{array}{c}\text { Outpatient } \\
\text { healthcare } \\
\text { facilities } / 10.00 \\
0 \text { inhabitants }\end{array}$ \\
\hline $\begin{array}{c}\text { Natural } \\
\text { increase/ } \\
10.000 \\
\text { inhabitants }\end{array}$ & $\begin{array}{l}\text { No of private } \\
\text { economic } \\
\text { activities }\end{array}$ & $\begin{array}{l}\text { Municipal } \\
\text { investment } \\
\text { expenditure/ } \\
\text { inhabitant }\end{array}$ & $\begin{array}{c}\text { Foreign tourists } \\
\text { accommodated } / 100 \\
0 \text { inhabitants }\end{array}$ & $\begin{array}{l}\text { Cubic volume of } \\
\text { delivered buildings } \\
\text { / inhabitant }\end{array}$ & $\begin{array}{l}\text { Environmental } \\
\text { protection } \\
\text { investment/ } \\
\text { inhabitant }\end{array}$ \\
\hline $\begin{array}{l}\% \text { of } \\
\text { population in } \\
\text { productive } \\
\text { age }\end{array}$ & $\begin{array}{l}\text { No of national } \\
\text { commercial } \\
\text { companies }\end{array}$ & $\begin{array}{l}\text { PIT income/ } \\
\text { employed } \\
\text { inhabitant }\end{array}$ & $\begin{array}{c}\text { Tourism } \\
\text { accommodation } \\
\text { units } / 1000 \\
\text { inhabitants }\end{array}$ & $\begin{array}{c}\text { Km of water-supply } \\
\text { and sanitation } \\
\text { network/inhabitant }\end{array}$ & $\begin{array}{c}\text { Primary and } \\
\text { Lower secondary } \\
\text { education } \\
\text { expenditure/pupil }\end{array}$ \\
\hline Birth rate & $\begin{array}{c}\text { No of } \\
\text { commercial } \\
\text { companies with } \\
\text { foreign capital }\end{array}$ & $\begin{array}{l}\text { Budget deficit/ } \\
\text { inhabitant }\end{array}$ & $\begin{array}{c}\text { No of overnight } \\
\text { stays }\end{array}$ & $\begin{array}{c}\text { Residential water } \\
\text { system connections } \\
\text { /inhabitant }\end{array}$ & $\begin{array}{l}\% \text { of population } \\
\text { connected to } \\
\text { wastewater } \\
\text { treatment plants }\end{array}$ \\
\hline
\end{tabular}

Source: Elaborated by the author based on GUS data.

Benchmarking methods were applied to capture the expected change in indicators between geothermal municipalities compared to a matched group of municipalities without geothermal resources. Using the benchmark concept deployed by Davis and Davis $^{45}$ and Rondo-Brovetto and Saliterer ${ }^{46}$, each of the nine geothermal municipalities were examined in relation to a benchmark group of five municipalities of a similar size (population and $\mathrm{km} 2$ ), administrative profile and geographical location. There were 54 observations in total ( 6 indicator categories $\times 9$ benchmark groups) with the average performance of the five benchmark municipalities being compared with the corresponding geothermal municipality. On the basis of this benchmarking model, the following steps were followed to assess the extent to which local development measures had been

${ }^{45}$ R.J. Davis, R.A. Davis, Framework for Managing Process Improvement: Benchmark Tutorial, „System Research and Applications”, Corp. Arlington VA 1994.

${ }^{46}$ P. Rondo-Brovetto, I. Saliterer, Comparing regions, cities, and communities: local government benchmarking as an instrument for improving performance and competitiveness, „The Innovation Journal: The Public Sector Innovation Journal”, 2007/12(3). 
impacted: each variable was identified as either having stimulated or suppressed local development; data were then normalized, and a synthetic indicator generated.

Since the resulting diagnostic variables would consist of a set of local development stimulants, the aim of multi-criteria analysis is to compare all the stimulants from multiple perspectives. It does so by exploring a complex phenomenon that, while it cannot be measured directly, can be assessed by way of a synthetic indicator which is able to capture changes in the development performance indicators for geothermal and benchmark municipalities.

The Zero Unitarization Method (ZUM), a widely used method of examining the impact of stimulants to (or destimulants of) regional and local growth, was used to normalize all 24 diagnostic variables. In this specific case, the ZUM is used to discover if the fact of having geothermal resources activities is the cause of a socio-economic growth in the municipalities, compared to other municipalities from the same region. To normalize the variables, Kukuła's ${ }^{47}$ ZUM formula for stimulant variables was applied. The resultant scores are placed within a closed interval [0,1] with values closer to "1" indicating that the stimulant variable under scrutiny is associated with a positive change in overall local development. Similarly, the synthetic indicator - the arithmetic mean of the aggregation function with all diagnostic variables normalized - is also represented by a value in the $[0,1]$ interval. The higher the value of the resultant synthetic indicators, the higher the level of the geothermal municipalities' local development potential compared to the benchmark municipalities. Moreover, the adopted methodology allows the results to be ranked, i.e. indicating which variables (or combination of variables) are associated with higher and lower levels of local development performance. For practical reasons, the study adopted the assumption that each of the variables analyzed has the same effect on the level of the complex phenomenon under scrutiny i.e. local socioeconomic development $^{48}$, giving all variables equal weights. The resulting synthetic measure of development is represented in Table 2.

The score for each category summarizes the results for all four variables defining it. The total performance indicator is arrived at by averaging the final score for the six indicator categories, thereby permitting a comparison to be made between the dynamics of local development for each geothermal municipality and its benchmark group, including observations relating to year-on-year changes in the variables. Since the statistical observation addresses the 24 diagnostic variables that were applied to the 54 municipalities used for benchmarking purposes, it is possible to confirm our hypothesis that the higher the value of the indicator the greater is the contribution to local development. In this study, all indicators consist of socio-economic development measures (see Table 1) and, in line with its initial research questions, the scores should be higher in the case of geothermal municipalities than the benchmarked municipalities that

Table 2. Compilation of ZUM results for the development indicators categories

${ }^{47}$ K. Kukuła, Metoda unitaryzacji zerowanej. Wydaw. Naukowe PWN. Warszawa 2000.

${ }^{48}$ Appenzeller D., Metodologiczne problemy opisu $i$ prognozowania kondycji finansowej, [w:] Dittmann P., Szanduła J. (red.), „Prognozowanie w zarządzaniu firmą”, Indygo Zahir Media, Wrocław 2008. 


\begin{tabular}{|c|c|c|c|c|c|c|c|c|}
\hline \multicolumn{9}{|c|}{ Indicator categories 1995-2015 } \\
\hline Municipality & $\begin{array}{l}\text { Popula- } \\
\text { tion } \\
\text { Resources }\end{array}$ & $\begin{array}{c}\text { Local } \\
\text { economy }\end{array}$ & $\begin{array}{c}\text { Local } \\
\text { government }\end{array}$ & Tourism & $\begin{array}{c}\text { Infra- } \\
\text { structure }\end{array}$ & $\begin{array}{l}\text { Quality } \\
\text { of life }\end{array}$ & $\begin{array}{c}\text { Total } \\
\text { development }\end{array}$ & $\begin{array}{c}\text { Average } \\
\text { annual } \\
\text { change } \\
(\%)\end{array}$ \\
\hline Mszczonów & 0,39 & 0,62 & 0,54 & 0,22 & 0,2 & 0,6 & 0,43 & 1,08 \\
\hline Benchmark & 0,47 & 0,38 & 0,47 & 0,31 & 0,36 & 0,38 & 0,39 & 0,05 \\
\hline Uniejów & 0,28 & 0,45 & 0,71 & 0,8 & 0,58 & 0,3 & 0,52 & 0,77 \\
\hline Benchmark & 0,5 & 0,38 & 0,37 & 0,18 & 0,4 & 0,36 & 0,36 & 0,03 \\
\hline Zakopane & 0,49 & 0,83 & 0,8 & 0,89 & 0,81 & 0,82 & 0,77 & 0,04 \\
\hline Benchmark & 0,57 & 0,43 & 0,43 & 0,12 & 0,21 & 0,39 & 0,36 & $-0,22$ \\
\hline $\begin{array}{c}\text { Bukowina } \\
\text { Tat. }\end{array}$ & 0,49 & 0,6 & 0,51 & 0,94 & 0,32 & 0,45 & 0,55 & 1,16 \\
\hline Benchmark & 0,44 & 0,36 & 0,46 & 0,06 & 0,36 & 0,4 & 0,34 & 0,57 \\
\hline $\begin{array}{c}\text { Biały } \\
\text { Dunajec }\end{array}$ & 0,66 & 0,5 & 0,47 & 0,85 & 0,38 & 0,35 & $\mathbf{0 , 5 3}$ & 0,28 \\
\hline Benchmark & 0,44 & 0,46 & 0,44 & 0,07 & 0,42 & 0,33 & 0,36 & 0,76 \\
\hline Poronin & 0,47 & 0,54 & 0,41 & 0,92 & 0,45 & 0,44 & 0,54 & 0,09 \\
\hline Benchmark & 0,46 & 0,39 & 0,46 & 0,13 & 0,37 & 0,33 & 0,36 & 0,04 \\
\hline Szaflary & 0,67 & 0,42 & 0,39 & 0,21 & 0,31 & 0,29 & $\mathbf{0 , 3 8}$ & 0,20 \\
\hline Benchmark & 0,41 & 0,39 & 0,28 & 0,31 & 0,31 & 0,25 & $\mathbf{0 , 3 3}$ & 0,17 \\
\hline $\begin{array}{c}\text { Stargard } \\
\text { Szcz. }\end{array}$ & 0,21 & 0,33 & 0,28 & 0,06 & 0,32 & 0,37 & 0,26 & $-0,27$ \\
\hline Benchmark & 0,31 & 0,48 & 0,31 & 0,38 & 0,47 & 0,4 & 0,39 & 0,25 \\
\hline Pyrzyce & 0,59 & 0,52 & 0,27 & 0,21 & 0,34 & 0,47 & 0,4 & $-0,40$ \\
\hline Benchmark & 0,5 & 0,43 & 0,57 & 0,44 & 0,41 & 0,38 & 0,45 & 0,65 \\
\hline
\end{tabular}

Source: Elaborated by the author

have no such resources. The likely impact of harnessing geothermal energy on diverse aspects of local development would therefore include:

- Local economy. The relation was strongest in the case of the local economy indicator, with 8 out of 9 geothermal municipalities scoring higher than the corresponding benchmark group; this indicates that there exist opportunities for direct and induced economic activities related to the harnessing of geothermal energy. It is likely that the impact on job creation, investment attractiveness and induced entrepreneurship would derive from the multipurpose application of geothermal energy products and accompanying economic activities. Additionally, the aspect of having green energy generated by geothermal plants is an attractive proposition for potential investors both national and foreign.

- Quality of Life. There was a significant result in the quality of life indicator category, with 6 out of 9 scores higher than the benchmarked municipalities; investment in geothermal projects and related ventures had resulted in improvements in both environmental and human aspects of life.

- Public Finance. There was also an observable impact on the size of local government budgets in 6 out of 9 municipalities, since geothermal-driven activities (both direct and induced) are able to stimulate public income growth and investment. 
- Population. The relatively positive result of in the category of population resources (5 out of 9 cases) indicates that inhabiting a locality that benefits from the exploitation of geothermal resources is likely to promote local demographic stability by helping both to retain the existing population and to attract new residents.

- Tourism. The tourism indicator also was higher in 5 out of 9 municipalities. This outcome is explained by visitors to the geothermal spas, health centers and the creation of associated services. However, optimism regarding this effect should not be exaggerated because Zakopane, Bukowina Tatrzańska, Biały Dunajec and Poronin are all have a long historical tradition of spa tourism. On the other hand, in Mszczonów, Uniejów and Szaflary tourism was nonexistent before the launch of their geothermal energy projects and the subsequent flourishing of associated health and recreational facilities.

- Infrastructure. Somewhat contrary to expectations (based on the fact that geothermal water and heat is distributed to the local recipients throughout collective systems), the lowest indicator growth was in the infrastructure category with only 4 out of 9 municipalities having higher scores than the corresponding benchmark cases. However, it should not indicate a neutral or negative relation between infrastructure development and geothermal resource since limitations in the database prevented all the relevant features of local infrastructure from being tested.

- Total development. In 7 out of 9 cases, the total development indicator (the synthetic indicator) depicting the scale of local development progress over the 1995-2015 period was higher for the geothermal municipalities than the corresponding benchmarked municipalities. Only Pyrzyce and Stargard Szczeciński had scores lower (albeit only slightly) than the benchmark. This result can be interpreted as a general trend of faster growth and development among geothermal municipalities compared to benchmarked municipalities without access to this energy source. As discussed above, aside from the absence of geothermal energy, the benchmark groups have very similar characteristics to the corresponding geothermal municipalities. It is therefore accurate to use the synthetic indicator to compare variations in the accumulated performance indicators. The synthetic indicator provides a means of identifying and measuring the development gap attributable to the exploitation of geothermal energy, based upon the selected development indicators.

- Average annual change. The annual change score represents the percentage growth in a municipality's development each year, based on the average of the differences between each year's total development indicator score. Here, the results reflect those provided by the synthetic indicator, underlining the advantages of geothermal municipalities over their benchmarked comparators. In the majority of cases, the geothermal municipality experience faster and more positive growth, with the exception of three municipalities: Stargard Szczeciński and Pyrzyce (municipalities that had already scored below their benchmarks in the total development category) and Biały Dunajec (which had not). The bigger the difference between the scores of geothermal municipalities and benchmark group the greater the development impact of local geothermal-based activities is likely to be. 
Visualization of the above-mentioned scores helps to illustrate changes in the local development performance from the launch date of the local geothermal industry. In Figures 1 and 3 below, this base year (different in each of the geothermal municipalities) provides an index of 100 for all the indicators of each geothermal municipality and its benchmark group; the total development score is superimposed (since it summarizes all 24 diagnostic variables), and a trend line traces the growth of the total performance indicator. In the case of six geothermal municipalities (Mszczonów, Uniejów, Zakopane, Bukowina Tatrzańska, Szaflary, and Pyrzyce), the total development indicator deviates positively from the year of initiation of the geothermal network and therefore a tendency for development indicators growth is confirmed. In contrast, Biały Dunajec, Poronin and Stargard Szczeciński do not display a significant growth tendency from the launch of their

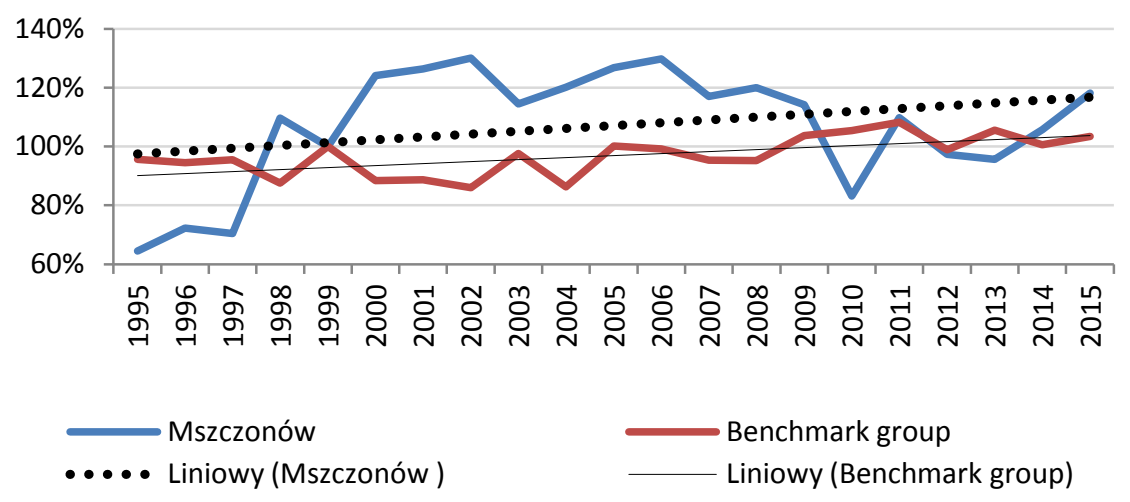

Figure 1. Mszczonów - score of total development indicator vs. benchmark group $(1999=100)$

Source: Elaborated by the author

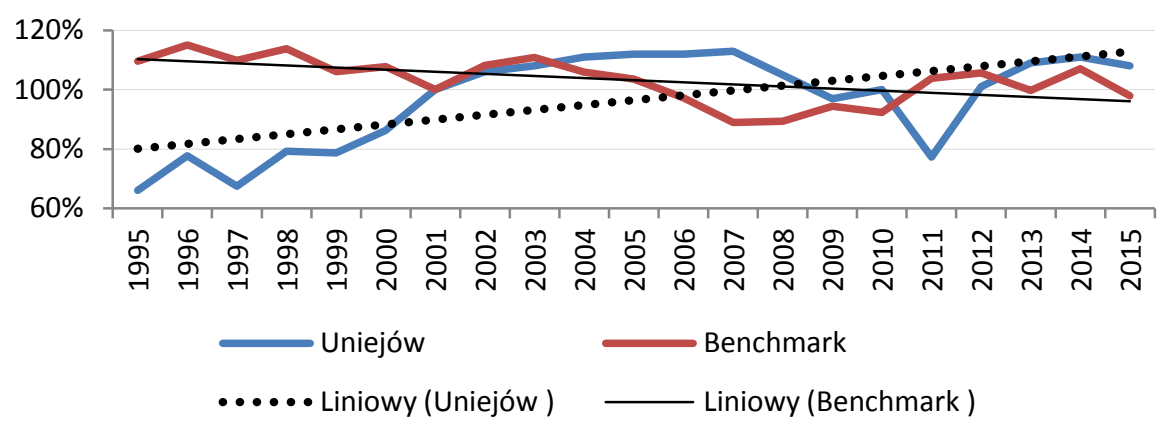

Figure 2. Uniejów - score of total development indicator $v s$ benchmark group $(2001=100)$

Source: Elaborated by the author. 


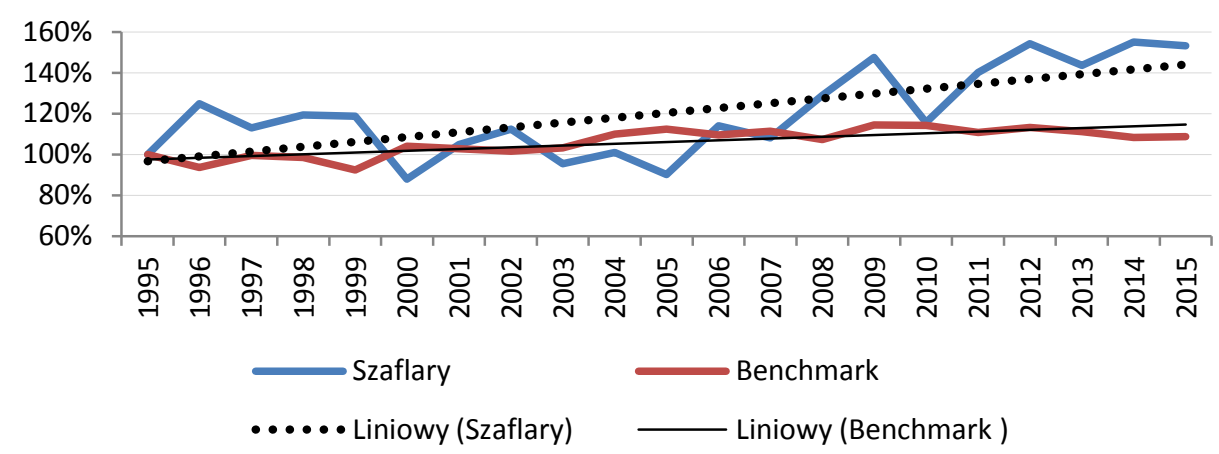

Figure 3. Szaflary - score of total development indicator vs. benchmark group $(1995=10)$

Source: Elaborated by the author.

geothermal networks. It should be noted that, while not quantitatively presented below, we cannot reject the hypothesis that these municipalities also enjoyed some (albeit more modest) local socio-economic benefits as a result of harnessing geothermal resources. Due to the fact that they display the most marked relation between the growth of development indicators and the establishment of geothermal installations, the results for Mszczonów, Uniejów and Szaflary have been used in the figures below. Though the geothermal municipalities of Zakopane and Bukowina Tatrzańska display the same trend, they have not been visualized here.

From the launch year of geothermal resource exploitation, each of the geothermal municipalities exhibits a significant upward gradient in the total development indicator line, a phenomenon not observed for the benchmarked municipalities. The dashed line for the geothermal municipality and the solid line for the benchmark group capture the general development trend. The dashed lines are steeper than the solid ones, indicating faster growth in the development indicators in the case of those municipalities (and the respective local economies) exploiting geothermal power.

\section{CONCLUSIONS}

The aim of this paper has been to ascertain if geothermal resource exploitation generates effects that reflect in local development indicators. From the data analysed, the variables constructed and the results observed, it can be concluded that significant positive changes in local development can be triggered by the harnessing of geothermal resources. The strongest impact is observed in the local economy in the form of employment generation. Additionally, the geothermal resource industry appears to contribute to local government budgets and positively influences the quality of life in a municipality. The positive effects can also be verified in the way in which geothermal heat and water promote tourism expansion and by retaining population in and attracting new residents to geothermal areas. However, it should be stressed that these results depend upon the specific development indicators adopted, the data that was available and the choice of the geothermal municipalities and benchmarked municipalities. The main findings appear to confirm the hypothesis that harnessing geothermal power stimulates local development, since high scores for indicators of local economic development, improvement in the 
quality of life and demographic sustainability were observed for geothermal municipalities, while no significant changes in the same indicators were found in the case of the benchmarked groups. This conclusion reflects the accepted definition of local development as socio-economic progress, achieved via the improvement of livelihoods and living conditions, the sustainable exploitation of endogenous resources, and the progressive empowerment of the local population. Seen from this perspective, geothermal resources harnessed in and by the local community can become an important driver of local development. The advantage of this energy source has attracted the attention of national and local policymakers, since its effective utilization relies above all in the competences of local authorities, and the capacity of this renewable endogenous resource to stimulate local development is still underexploited.

On the basis of this initial study, further research can be conducted into the potential value added that the exploitation of geothermal resources could generate for localities. However, the crucial importance of having an adequate time frame in which to observe trends in local development indicators cannot be underestimated. It would be perfectly feasible to apply the methodology adopted here to other sets of municipalities with geothermal resources. Indeed, the same methodology could be adapted for use with other renewable resources that are relatively place-specific i.e. are currently produced and consumed in a specific locality and that may have some potential for future market expansion.

\section{REFERENCES}

[1] Akella A.K., Saini R.P., Sharma M.P., Social, economical and environmental impacts of renewable energy systems, ,Renewable Energy”, 2009/34(2), pp. 390-396.

[2] Andritsos N., Dalampakis P., Kolios N., Use of geothermal energy for tomato drying, „GeoHeat Center Quarterly Bul”, 2003/24(1), pp. 9-13.

[3] Appenzeller D., Metodologiczne problemy opisu i prognozowania kondycji finansowej, [w:] Dittmann P., Szanduła J. (red.), „Prognozowanie w zarządzaniu firmą”, Indygo Zahir Media, Wrocław 2008.

[4] Asif M., Muneer T., Energy supply, its demand and security issues for developed and emerging economies, „Renewable and Sustainable Energy Reviews”, 2007/11(7), pp. 1388-1413.

[5] Brander J.A., Taylor M.S., The simple economics of Easter Island: A Ricardo-Malthus model of renewable resource use, „American economic review”, 1998, pp. 119-138.

[6] Bujakowski W., Wykorzystanie wód termalnych w Polsce (stan na rok 2009), „Przegląd Geologiczny”, 2010/58(7), pp. 580-588.

[7] Chakravorty U., Roumasset J., Tse K., Endogenous substitution among energy resources and global warming, „Journal of Political Economy”, 1997/105(6), pp. 1201-1234.

[8] Coffey W.J., Polese M., The concept of local development: a stages model of endogenous regional growth, „Papers in Regional Science”, 1998/55(1), pp. 1-12.

[9] Dalton T.R., Coats R.M., Asrabadi B.R., Renewable resources, property-rights regimes and endogenous growth, „Ecological Economics”, 2005/52(1), pp. 31-41. 
[10] Davis, R.J. and Davis, R.A., Framework for Managing Process Improvement: Benchmark Tutorial, „System Research and Applications”, Corp. Arlington VA 1994.

[11] Del Río, P., Burguillo, M., Assessing the impact of renewable energy deployment on local sustainability: Towards a theoretical framework, „Renewable and sustainable energy reviews", 2008/12(5), pp.1325-1344.

[12] Fridleifsson, I.B., Geothermal energy for the benefit of the people, „Renewable and sustainable energy reviews", 2001/5(3), pp.299-312.

[13] Gędek, S., Strojny, J., Kościółek, M., Wykorzystanie benchmarkingu w zarządzaniu strategicznym administracją publiczna, „Przedsiębiorczość i Zarządzanie”,2013/14(12, cz. 2 Zarządzanie w XXI wieku. Menedżer innowacyjnej organizacji. Część II), pp.127-142.

[14] International Renewable Energy Agency (IRENA), Renewable Energy and Jobs. Annual Review 2016,http://www.irena.org/DocumentDownloads/Publications/ IRENA_RE_Jobs_Annual_Review_2016.pdf (accessed 10.07.2016).

[15] Jarczewski W., Huculak M., Dej M., Wykorzystanie Energii Geotermalnej w Polsce The use of geothermal energy in Poland, „Prace Geograficzne”, 2015(141), p. 87.

[16] Johansson T.B., Kelly H., Reddy A.K.N., Williams R.H. Renewable Fuels and Electricity for a Growing World Economy: Defining and Achieving the Potential, „Energy Studies Review”, 1992/4(3), pp. 201-212.

[17] Kagel A., A handbook on the externalities, employment, and economics of geothermal energy. Geothermal Energy Association, Washington DC, October 2006.

[18] Kępińska B., Geothermal energy country update for Poland, 2010-2014, „Proceedings World Geothermal Congress", 2015, (p. 11).

[19] Kobylińska U., Glińska E., Wykorzystanie benchmarkingu w doskonaleniu systemów zarządzania placówkach samorządu terytorialnego, [w:] B. Plawgo (red), „Polska Wschodnia - zarządzanie rozwojem", WSAP, Białystok 2008.

[20] Kożuch A., Rola samorzadu terytorialnego we wspieraniu rozwoju lokalnego, „Instrumenty zarządzania rozwojem w przedsiębiorczych gminach”, 2011, pp. 9-26.

[21] Kukuła K., Metoda unitaryzacji zerowanej. Wydaw. Naukowe PWN, Warszawa 2000.

[22] Lehr U., Nitsch J., Kratzat M., Lutz C., Edler D., Renewable energy and employment in Germany, „Energy policy”, 2008/36(1), pp. 108-117.

[23] Lund J.W., Freeston D.H., World-wide direct uses of geothermal energy 2000, „Geothermics”, 2001/30(1), pp. 29-68.

[24] Malecki E., Jockeying for position: what it means and why it matters to regional development policy when places compete, „Regional studies”, 2004/38(9), pp. 1101$-1120$.

[25] Ney R., Zasoby energii geotermalnej w Polsce i możliwe kierunki jej wykorzystania, [w:] Materiały z seminarium naukowego pn. „Problemy wykorzystania energii geotermalnej i wiatrowej w Polsce”, Wyd. IGSMiE PAN, Kraków-Zakopane 1997.

[26] Olewiler N., Environmental sustainability for urban areas: The role of natural capital indicators, „Cities”, 2006/23(3), pp. 184-195. 
[27] Panwar N.L., Kaushik S.C., Kothari S., Role of renewable energy sources in environmental protection: a review, „Renewable and Sustainable Energy Reviews”, 2011/15(3), pp. 1513-1524.

[28] Pike A., Rodríguez-Pose A., Tomaney J., Local and regional development, Routledge NY 2006.

[29] Pires S.M., Fidélis T., Ramos T.B., Measuring and comparing local sustainable development through common indicators: Constraints and achievements in practice, „Cities”, 2014/39, pp. 1-9.

[30] Plummer P., Tonts M., Martinus K., Endogenous growth, local competitiveness and regional development: Western Australia's Regional Cities, 2001-2011, „Journal of economic and social policy", 2014/16(1), p. 1-29.

[31] Ragwitz M., Schade W., Breitschopf B., Walz R., Helfrich N., Rathmann M., Resch G., Panzer C., Faber T., Haas R., Nathani C., The impact of renewable energy policy on economic growth and employment in the European Union, European Commission, DG Energy and Transport, Brussels, Belgium 2009.

[32] Romer P.M., The origins of endogenous growth, „The journal of economic perspectives", 1994/8(1), pp. 3-22.

[33] Rondo-Brovetto P., Saliterer I., Comparing regions, cities, and communities: local government benchmarking as an instrument for improving performance and competitiveness, „The Innovation Journal: The Public Sector Innovation Journal”, 2007/12(3).

[34] Rybach L., The future of geothermal energy and its challenges, „Proceedings World Geothermal Congress April 2010”, 2010 (vol. 29).

[35] Sánchez-Velasco R., López-Díaz M., Mendoza H., Tello-Hinojosa R., New CFE geothermal village power plant in Mexico bestows local residents with prosperity and children with ice cream, Comisión Federal de Electricidad, Mexico 2003.

[36] Scipioni A., Mazzi A., Mason M., Manzardo A., The Dashboard of Sustainability to measure the local urban sustainable development: The case study of Padua Municipality, „Ecological indicators”, 2009/9(2), pp. 364-380.

[37] Strojny J., Baran M., Przedsiębiorczość i innowacyjność w zarządzaniu rozwojem JST, „Przedsiębiorczość-Edukacja”, 2014/10, pp. 187-198.

[38] Szewczuk A., Kogut-Jaworska M., Zioło M., Rozwój lokalny i regionalny. Teoria i praktyka, Wydaw. CH Beck, Warszawa 2011.

[39] Szymańska D., Chodkowska-Miszczuk J., Endogenous resources utilization of rural areas in shaping sustainable development in Poland, „Renewable and Sustainable Energy Reviews", 2011/15(3), pp. 1497-1501

[40] Turski M., Sekret R., Konieczność reorganizacji systemów ciepłowniczych w świetle zmian zachodzacych $w$ sektorze budowlano-instalacyjnym, „Rynek Energii”, 2015/4(119), pp. 27-34.

[41] U.S. Environmental Protection Agency's (EPA), How Small Towns and Cities Can Use Local Assets to Rebuild Their Economies: Lessons From Successful Places, 2015, https://www.epa.gov/sites/production/files/2015 (accessed 10.07.2016). 
[42] Walker G., Hunter S., Devine-Wright P., Evans B., Fay H., Harnessing community energies: explaining and evaluating community-based localism in renewable energy policy in the UK. „Global Environmental Politics”, 2007/7(2), pp. 64-82.

[43] Wei M., Patadia S., Kammen D.M., Putting renewables and energy efficiency to work: How many jobs can the clean energy industry generate in the US? „Energy policy", 2010/38(2), pp. 919-931.

[44] Weisbrod G., Weisbrod B., Measuring economic impacts of projects and programs, Economic Development Research Group, 10 (1997).

[45] Wright P.M., Ward S.H., Ross H.P., West R.C., State-of-the-art geophysical exploration for geothermal resources, „Geophysics”, 1985/50(12), pp. 2666-2696.

\section{PODEJŚCIE DO ZASOBÓW GEOTERMALNYCH W KONTEKŚCIE ROZWOJU REGIONALNEGO W POLSCE}

Studia nad energią geotermalna angażują różne dyscypliny naukowe ze względu na przewagę niewyczerpalności zasobów geotermalnych nad innymi zasobami odnawialnymi oraz na fakt powszechności jej wykorzystania na całym świecie. Oprócz tych parametrów technicznych zasoby geotermalne cechują się endogennym charakterem. Oznacza to, że optymalna eksploatacja zasobu odbywa się w miejscu w jego lokalizacji. Celem tego artykułu jest zbadanie możliwego scenariusza wpływu zasobów geotermalnych na rozwój lokalny, który wywodzi się z jego pierwotnej funkcji energetycznej. Energia geotermalna wykorzystywana lokalnie może pozytywnie wpływać na gospodarkę regionu w bezpośredni i pośredni sposób. Zainteresowanie tym zasobem wypływa również z założeń zrównoważonego rozwoju krajowych planów energetycznych i ambicji Unii Europejskiej, aby znacząco uwzględnić energię geotermalną w bilansach energetycznych. Lokalna produkcja ciepła geotermalnego i wody powinna zatem stać się priorytetem lokalnego bezpieczeństwa energetycznego dla gmin lub regionów, które posiadają dogodne warunki geologiczne dla eksploatacji geotermii. Jednakże, lokalny aspekt geotermii jako czynnika rozwojowego jest wciąż marginalizowany w istniejącej literaturze i przez praktyków. Ten artykuł podejmuje próbę odpowiedzi na tą lukę i ustalenia lokalnych wskaźników rozwoju powiązanych z lokalnym wykorzystaniem energii geotermalnej. Analizę przeprowadzono na przykładzie miejscowości użytkujących geotermię w Polsce ze względu na wysoki potencjał zasobu, mimo niskiego wykorzystania i znaczenia dla władz w skali kraju. Empiryczna analiza wybranych gmin ma doprowadzić do określenia udziału potencjału zasobu geotermalnego w wskaźnikach rozwoju gmin. Teoretyczna koncepcja tematu została zawarta w teorii rozwoju endogenicznego i definicjach rozwoju lokalnego.

Słowa kluczowe: zasoby geotermalne, odnawialne źródła energii, rozwój lokalny, endogeniczne czynniki wzrostu.

DOI:10.7862/rz.2016.hss.68

Przestano do redakcji: wrzesień $2016 r$.

Przyjęto do druku: grudzień 2016 r. 